\title{
Paris and the Climate
}

\section{Dear Reader,}

The Paris climate change agreement can now be put into effect. The European Parliament has quickly ratified the agreement, in order not to hold back its progress any longer. It is rare for bureaucratic institutions on a national and a European level to react so rapidly and decisively. This made it possible for the international agreement to come into force on 7 November 2016 and for this fact to be celebrated at the UN Climate Change Conference in the Moroccan city of Marrakech, which is taking place at the same time. Countries not known for their efforts to halt climate change, such as China, India, Mexico, the USA and 60 other nations, have pushed ahead with efforts to restrict the rise in global warming to significantly less than $2{ }^{\circ} \mathrm{C}$ above its pre-industrial level. This means that the agreement quickly met the first criterion that it must be ratified by at least 55 states. The signature of the EU fulfils the second criterion, because the signatories must be responsible for at least $55 \%$ of global greenhouse gas emissions. The EU produces around $12 \%$ of the world's $\mathrm{CO}_{2}$ and would like to reduce this figure significantly, among other things by promoting electric vehicles.

As a result of the Paris agreement, many smaller countries have set themselves climate change targets for the first time. As reported in the German newspaper Frankfurter Rundschau, Germany is offering them technical assistance on how to reduce $\mathrm{CO}_{2}$ emissions and monitor the processes involved. "We want to enable these countries to set up transparent $\mathrm{CO}_{2}$ monitoring systems," explained Nicole Wilke, chief climate negotiator for Germany from the Federal Environment Ministry in Berlin.

One positive example is Morocco, which previously met $95 \%$ of its growing demand for energy using fossil fuels.
The country now plans to take a new approach. In February, King Mohammed VI formally opened the first of four parts of a huge solar park. The Noor 1 park was built by the Moroccan Agency for Solar Energy (Masen) in only two-anda-half years. It consists of more than 500,000 mirrors in the desert near Ouarzazate. According to the German newspaper FAZ, the $160 \mathrm{MW}$ solar power plant will supply 350,000 people with electricity. Morocco is currently an energy importer, but plans to export green electricity to Europe in the near future.

It would be wonderful if German utility companies and energy suppliers moved to renewable energy in the same way, so that electric vehicles could be genuinely carbon neutral. The latest decision to just bisect the $\mathrm{CO}_{2}$ emissions of German power plants until 2050 is for sure not really productive. Many potential customers are holding back from buying electric cars because the German electricity mix is dominated by coal. We report on the electric mobility project run by the municipality of Bad Homburg on page 8 .

Best wishes,

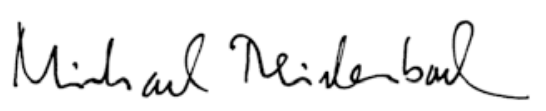

Dipl.-Ing. Michael Reichenbach Deputy Editor in Chief

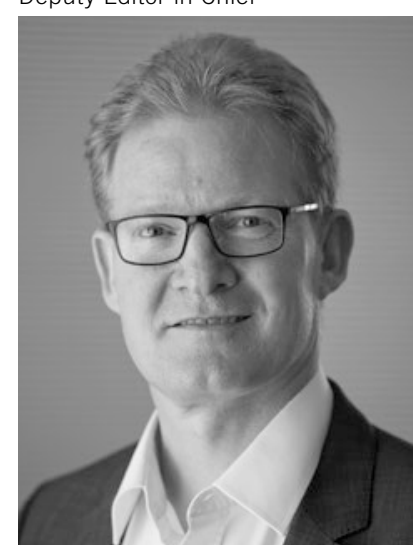

